\title{
HOTS based project in mechanical engineering department
}

\author{
Dewanti Ratna Pertiwi ${ }^{1, *}$ \\ ${ }^{1}$ Sekolah Tinggi teknologi Adisutjipto \\ ${ }^{1}$ dewantiratna@stta.ac.id \\ * corresponding author
}

\section{ARTICLE INFO}

\section{Article history}

Received : April 1, 2019

Revised : May 3, 2019

Accepted : May 27, 2019

Keywords

HOTS

Project

Mechanical Engineering

\begin{abstract}
PT)
Typ In this $21^{\text {st }}$ century education, preparing learners to have high order thinking skills (HOTS) is important to make them ready face the global era. HOTS (analyze, evaluate, create) is the continuous phases of LOTS (remember, understand, apply). HOTS in a project based instruction is proposed to be able to promote the skills needed in the 4.0 era (critical thinking, communication, creativity, and collaboration). This research focused on a HOTS-based project in a mechanical engineering, Adisutjipto College of Technology. Based on the observation in the previous semester, the students needed to improve their HOTS that the research applied an action research study. The projects were allocated in two course objectives; identifying the tools in mechanical engineering and identifying the components of an airplane. They were chosen due to the supported authentic materials exist in the college workshop laboratory, hangar, and airplane museum near the college. The results were the learners enjoyed the learning and improved the engagement in a group work, the critical thinking in finding fruitful information, the creativity in creating presentation, and the speaking skill in presenting in front of other people.The three main skills in HOTS; transferring knowledge, critical thinking, and problem solving were shown in each project. The 4C skills; creativity, collaboration, critical thinking, and communication also supported the HOTS improvement
\end{abstract}

This is an open access article under the CC-BY-SA license.

\section{Introduction}

The current educational demands are to prepare students for the $21^{\text {st }}$ century by integrating soft skills and ICT through some learning models. Ledward and Hirata (2011) state that the $21^{\text {st }}$ century skills are a the combinations of knowledge, specific skills, proficiency, and literacies to be successful in future work and real life. They add that the $21^{\text {st }}$ century skills also need technological literacy and include proficiency in critical thinking, problem solving, communication, and team work. HOTS (Higher Order Thinking Skills) is one the innovations that should be developed to prepare the learners ready to face the global competition in the $21^{\text {st }}$ century. HOTS is the continuous phase of LOTS (lower order thinking skills). In the Bloom Taxonomy, LOTS consists of remembering, understanding, and applying, while HOTS consists of analyzing, evaluating, and creating. The skills developed in the HOTS are known as 4C; collaboration, communication, creativity, and critical thinking. In relation to the English instruction, lecturers and teachers should implement learning that promotes or introduces students on HOTS through language skills. In this research, the HOTS is based on the project for mechanical engineering department. 
Based on the ESP need analysis of English for mechanical engineering department in Adisutjipto College of Technology conducted previously, the students need to be able to use English to support their learning in the three offered concentrations; aircraft maintenance, energy conversion, and material manufacture. The need analysis is developed into more specific course objectives accommodating the students' need in their considered future career. The course consists of mathematics, energy and temperature, material technology, tool, pipe and pipeline, safety first, aircraft construction, basic flight instrument, flight line, aerodynamics, pre-flight, and future career.

According to the observation on the previous semester, the students need to improve the HOTS that the goal of ESP can be reached more thoroughly. The HOTS needs to be improved since the students found difficulties in Bahasa Inggris 1 subject. The subject focuses on the grammar competence that the students tended to memorize the formula, understand the example, and apply the formula on the given tasks. It was challenging and difficult when the teacher asked some critical questions on the grammar. In addition, the students faced the problems on analyzing, evaluating, and creating the new information related the grammar. Once the teacher gave the mind mapping homework on Conjunction, there were still a lot of mistakes. Moreover, the average final mark of the subject was 59.5 which belongs to $\mathrm{C}$ in the range of 55-64.99. The instruction was rarely conducted in the project based and focused on individual drilling. Reflecting the condition, the lecturer tried to find solution for the following semester by proposing HOTS based project.

The HOTS based project was conducted on the two considered course objectives; identifying tools in mechanical engineering and identifying aircraft constructions. Both course objectives were selected due to the available authentic facilities around the campus such as workshop laboratories, hangar, and aircraft museum. The learning indicator of the first objective stated in the syllabus is the students are able to identify five hand tools, five fasteners, and 5 power tools and describe the functions. Meanwhile, the indicator of the second objective is the students are able to identify 20 basic aircraft constructions and describe the functions.

The project involved the combinations of technology in terms of multimedia and ICT. The students worked in groups of 4 to 5. They collected the pictures of authentic materials on the tools and aircraft constructions available in the college workshop laboratories, students' house, mechanic, hardware shops, hangar, and museum. The students took the authentic pictures with the group members using their mobile phone camera. Furthermore, in group, the students analyzed the tools and aircraft constructions, evaluated the information gathered from the various printed and digital sources, consulted with the lecturer, created presentation media, and presented the finding. There are many benefits of using technology in learning that has been studied in various studies. Robyler \& Doering (2013) say the use of technology in learning is believed to play a role in increasing participation, student motivation and being able to involve students in production work and in collaborative real learning. By combining the multimedia, the students are expected to enjoy the learning, engage their group work, and improve their presentation skills.

This research was conducted to improve the students' HOTS using project based instruction. The improvement was identified on how HOTS based project helps the students enjoy the learning and how HOTS based project improves the $4 \mathrm{C}$ skills in the mechanical engineering background. In relation to the further goals, this research is expected to contribute to improve the quality of English learning and teaching in the mechanical engineering department.

\section{HOTS}

Higher order thinking skill (HOTS) is needed in this $21^{\text {st }}$ Century that people can make a good judgment. Brookhart (2010) describes HOTS using three categories as "transfer, critical thinking, and problem solving" (p. 3). Anderson \& Krathwohl explain that HOTS means transferring meaningful learning by encouraging students to remember and apply what the students have learnt in their life (as cited in Brookhart, 2010, p.3). In addition, HOTS involves critical thinking that realized on the activities of reasoning, confirming, investigating, and exploring information to decide what to and not to believe. Later, the students with critical thinking can create wise judgment. The last, HOTS is a problem solving that equips students to be able to categorize problems and solve the problems in their learning and real life. In this case, thinking means students can solve problems and work creatively. 
There some advantages of developing students higher order thinking skills. Nagappan (2001) says teacher needs to develop the students' HOTS because the students thinking competencies increases the students language achievement. HOTS does not develop automatically without any stimulants. He argues that adults will think as children if they are not trained to think critically. Students' HOTS are developed when they are actively engaged in the collaborative problem solving instructions. Kemdikbud (2017) explains that HOTS assessment measures transferring concepts from one concept to other concepts, processing and applying information, correlating different information, using information to solve the problems, and understanding idea and information critically.

It is necessary to provide a program with an evaluation. In relation to evaluation higher order skill learning, Brookhart (2010) underlines some strategies. The first, the teacher should specifically and exactly decide the learning objective. The second, the teacher could design activities that require students to show the skills or knowledge. The third, the teacher could provide evidence to prove that the students have experienced HOTS activity. The fourth, the teacher could present materials for students to think such as introductory, visual, scenario, or material resources. The fifth, the teacher could use new material which is not included in the class. The sixth, the teacher could distinguish levels of difficulty from easy to difficult and level of thinking from lower to higher.

Sometimes people find difficulties in distinguishing the activities that need lower order thinking skill (LOTS) and higher order thinking skills (HOTS). Anderson and Krathwohl in Churches (2008) mention the revised Bloom Taxonomy that divided into LOTS and HOTS. LOTS consists of remembering, understanding, and applying, while HOTS consists of analyzing, evaluating, and creating as presented in Figure 1.

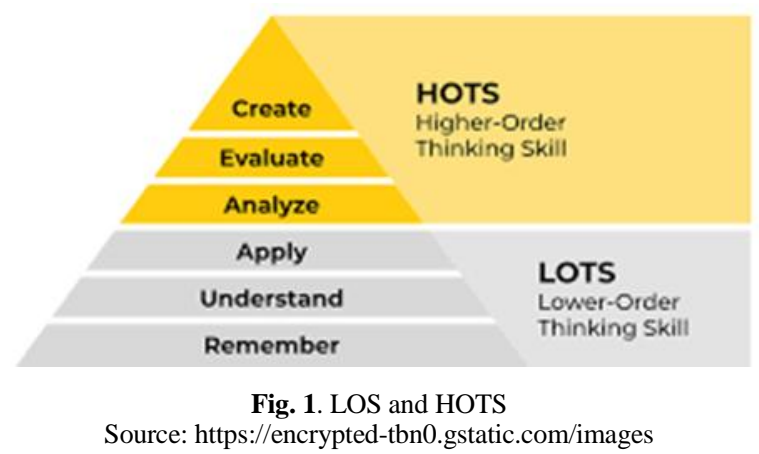

The first domain of HOTS is analyzing. The activities in analyzing might be comparing, organizing, finding, integrating, linking, or validating. The following level after analyzing is evaluating. The activities include checking, judging, monitoring, reviewing, collaborating, or testing. The highest skill level is creating. The activities consists of designing, producing, inventing, building, programming, or presenting.

In conclusion, higher order thinking skills involve three main processes. They are transferring, critical thinking, and problem solving. In these three processes, HOTS in a learning activity is intended to encourage the students to remember then apply the knowledge that they have learnt. In addition, HOTS trains the students not to make judgment before carefully examine and investigate the information. Furthermore, HOTS equips the students to solve the problem creatively. In evaluation HOTS learning, some steps need to prepare. Determining the learning objective, designing activities, providing evidence of the achievement, presenting supplementary materials, and classifying the levels of difficulty are things need to be well prepared by the teachers in conducting HOTS learning. Compared to LOTS (remembering, understanding, and applying), HOTS is more demanding that consists of analyzing, evaluating, and creating.

\section{Project Based Learning}

The intention of project work is to bring classroom activities closer to the experiences of the students on the basis of their natural development to promote change and innovation. Heyworth (2002) describes a project as an activity designed to observe current practice, offer change and test the application of change. PBL has some characteristics such as (1) it has a timeframe from start to 
finish, (2) it has to be planned, (3) it uses resources, (4) it requires evaluation in which established from the beginning, (5) it has an outcome in terms of product, and (6) it involves group work though it is still possible to work individually. Apel and Knoll in Andersen \& Kjeldsen (2015) add the characteristics of a project as it should relay to students' need and experience, symbolize something valuable in life, and have a certain duration.

Tan \& Chapman (2016) state that "a project based learning engages students in authentic learning through project work" (p. 35). This approach relies on applying knowledge to real world situations, initiating student's analysis and collaborations, and exercising critical thinking and creativity as proposed on the HOTS objective. Project based learning can generate the students' HOTS since they have to link and integrate several systems of knowledge, concepts and practices during their project work, which finally direct them to create new knowledge. The learning may change from teacher centered to student centered in which the teacher is in charge to provide guidance and advice. In this case, teachers direct students with their proposals and plans, encouraging them with the resources that they need to execute their project work. Laur (2013) explains authentic learning in a project work is designed to challenge students' desire in a deep investigation and promote critical thinking. The application of critical thinking to solve the challenging investigation generates an engagement and promotes a deep understanding of the core content. Involving students in authentic learning experience encourages students to have the skills needed in this $21^{\text {st }}$ Century that consist of critical thinking, collaboration, communication, and creativity. Developing the skills prepares students for their future such as college, career, and other parts of life outside the classroom rather than completing the exercise in the classroom.

Investigating open-ended questions may become the strategy to succeed project based learning. Krauss \& Boss (2013) quotes "in project-based learning, students gain important knowledge, skills, and dispositions by investigating open-ended questions to "make meaning" that they transmit in purposeful ways" (p.5). The project-based learning means the learning emphasizes on the students learning experience that the teacher prepares and guides projects without giving a lot of instruction. Monitoring is important in project-based learning. Students gain important knowledge, skills, and dispositions means the teacher develop the three areas all together based on the curriculum. Investigating open-ended questions means the teachers provide the questions to activate their curiosity and investigation. To make meaning means the learning is important, valuable and arouses investigation, analysis, creation, and unique conclusions. Transmitting in purposeful ways means the objective of the project is to serve invention and persuasion to transfer a light project structure but make the learning significant.

In conclusion, a project based learning is aimed to facilitate the students' experience in natural and authentic learning in a particular duration. The teacher roles as a supervisor and consultant the planned activities. Project based learning is mostly conducted collaboratively in group works and some are in individual works. Project based learning allows the students to apply HOTS; transfer, critical thinking, and problem solving.

\section{ESP}

ESP stands for English for Specific Purposes. It has become the field with increasing attention especially in the educational institutions that prepare the students to work in the offices or companies that involves English as a means communication either in the spoken or written communication. Nunan in Basturkmen (2010) says ESP is a "subcomponent of language teaching that holds its own approaches to curriculum development, materials design, pedagogy, testing and research"(p.2). This means, ESP has different characteristics with general English. ESP focusses on language in the thematic situation than language structure. The objective of ESP is not only integrating the four language skills but it is based on a need analysis. It is required to investigate the data on what the students need to achieve. Kaur (2007) says needs analysis is used in developing language curriculum. ESP instructors begins the instruction with needs analysis by gathering and analyzing students' information to determine appropriate objectives and content. In addition, Ayoub \& Khan (2017) argue that need analysis covers selecting the crucial needs and the most effective learning techniques to address the objectives.

Along the need and development, ESP varies into some areas. Basturkmen (2010) says, based on the branches, ESP is distinguished into EOP (English for Occupational Purposes), EAP (English for 
Academic Purposes), and EPP (English for Professional Purposes. Meanwhile, based on the themes, ESP varies into several fields such as Tourism English, Medical English, Engineering English, and Business English. Basturkmen (2006) states that specific language and target performance competencies are the main objectives of ESP. Both are important as the students need to use the ESP in their target workplace, academic, and professional development.

This research investigated ESP for mechanical engineering purposes in Adisutjipto College of Technology. One of the visions of mechanical engineering department is being able to compete globally. To realize this vision, it is important to design effective techniques put in all subjects including the English instruction. The use of English as an international language supports more colleges and universities place a focus on designing different kinds of ESP such as mechanical engineering English. Dragoescu and Sandra (2010) describes the main fields of mechanical engineering taught generally in Table 1.

Table 1.

Fields of mechanical engineering

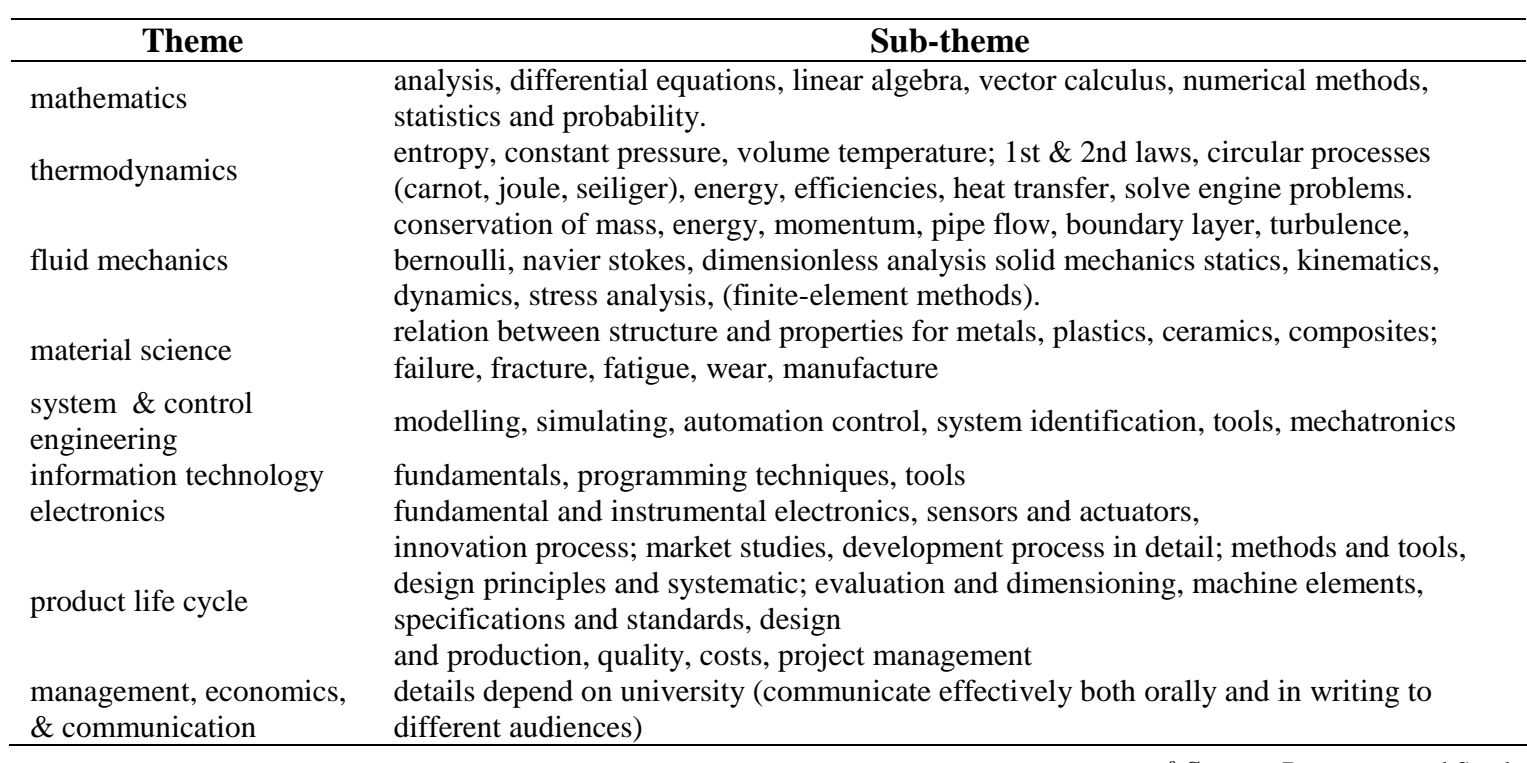

a. Source: Dragoescu and Sandra

An addition, the mechanical engineering department in Adisutjipto College should also include aerospace as the unique characteristics distinguished from other colleges. The materials are such as introduction to aerospace, aerodynamics, aircraft propulsion, aircraft construction, aircraft materials, aircraft maintenance, aircraft hydraulic pneumatic system, aircraft power plant maintenance, engine supplement system, aircraft system, and propulsion maintenance technique. In choosing the English materials, mechanical engineering English should cover the materials taught in the non-English subject that English might contribute in the academic development generally. Moreover, it should involve more authentic materials such as the real dialogue between a mechanic and the supervisor and an article of aerodynamics. To prepare the course, it is possible to conduct a pre-course survey on students' basic knowledge of certain topics that the students have acquired specific content-based knowledge either by quiz, discussion, or interview.

Technology is one of the factors that supports a successful ESP program. All areas of ESP pedagogy have been impacted by the ongoing development of new technologies. Bloch (2013) mentions technology has played a major role in ESP) in two different ways. Firstly, technology is used as a tool for assisting traditional types of language learning. Secondly, technology is used as a tool for creating new forms of communicating. $\mathrm{Li}$ (2018) states the Internet provides ESP teachers with a new tool that engages students in communication, links the intercultural gap, collaborates in their professional community and accesses relevant information to their discipline. For example, a teacher can use programs like Kahoot to create direct quiz in the classroom or Edmodo to create a blended learning such as giving an online quiz inside and outside the classroom. Technology also has been applied in a variety of ESP instructions to create contexts for communicating with oral, written, and visual modes of discourse. These include chat, email, blog, and other newer forms of 
technologies. The problem arises in selecting the most appropriate technologies for the types of learning and how the technologies affect the learning goals. Decisions about the selected technology can be connected to the more traditional decisions made about the objectives for a curriculum. ESP teachers have long relied on needs assessment for selecting the goals of their curricula.

\section{Previous research study}

There were some research studies conducted previously that inspire this study. The first, Fajariyah (2018) conducted an action research study for the $9^{\text {th }}$ graders of SMP N 5 Panggang, Gunungkidul. She focused on the HOTS based info-graphic project in the report text learning. The results were the project could make the students happy, improve the students' involvement, improve the students' understanding on the report text, improve the students' speaking skill and describe animals, improve the students' ICT skill, and integrate the students' thinking skill. The second, Setiawan \& Bharati (2018) conducted an R \& D study for the $10^{\text {th }}$ graders of SMA N 15 Semarang. They developed HOT project based speaking assessment to stimulate the students' critical thinking and creativity. The results were the assessment could stimulate the students' critical thinking and creativity in English learning. The students also improved the speaking test score, the participation in the teaching and learning, the ability to write drama script, the ability to perform the drama.

In conclusion, ESP is an English instruction based on the specific goals to facilitate the academic, occupation, or profession purposes by selecting thematic fields. ESP begins with a need analysis; the process to investigate and analyze the learners' needs and the learning needs. Mechanical engineering English in Adisutjipto College of Technology is conducted based on the need analysis also the vision and vision. Technology plays important roles in ESP such as the tools for assisting traditional language learning and creating new forms of communicating.

\section{Method}

The research was conducted in Mechanical Engineering Department, Adisutjipto College of Technology Yogyakarta. This college stands under the foundation controlled by the former air force staff. The distinctive characteristic is the students are taught some matters on aerospace including the mechanical engineering department. The study engaged two classes of the students taking Bahasa Inggris 2 subject in which it belongs to the main subject package in Semester 2. The students consists of 56 students from 2018 grade and 21 students repeaters. The research was executed in Semester 2 of academic year 2018/2019.

As the aim of this study is to explore how particular technique improves a problem, an action research (AR) was carried out. Tomal (2010) describes that the researcher in action research is concerned in applying methodical processes in solving instructional cases and generated to find the solution. Furthermore, Burns (2010) adds that AR is a critical, reflective teaching, supported by systematic approach to solve the existing problems in educational program. The focus of AR is reflecting way in problematic condition to propose changes, better quality, and concrete improvement. The data incorporated both qualitative and quantitative data formulized from some sources, i.e. the journal log, observation sheet, questionnaire, test, and interview.

In order to conduct a comprehensive action research, some research instruments are accessed. The instruments was adapted from McNiff, et.al (2002) and Henning, et.al. (2009). The first instrument is journal-log that is the columns for writing clarifications on the students' activities. The second instrument is observation sheet that help the researcher to make improvement in teaching learning process. The third instrument is the interview purposed to find the problems happen in the classroom and explore the respond and opinion on the use of HOTS based project. The fourth is comparing the students' achievement before and after being given the HOTS based project, i.e. marks in Bahasa Inggris 1, marks in the Tools presentation, and marks in the Aircraft presentation. The last instrument is distributing questionnaire after AR to investigate the students' opinion and respond on the HOTS based project.

The procedures of conducting the research were on Figure 2: 
Cycle 1

\begin{tabular}{|c|c|c|c|c|}
\hline $\begin{array}{l}\text { Identifying } \\
\text { problem } \\
\text { (observation, } \\
\text { final mark, } \\
\text { interview) }\end{array}$ & Plan & $\begin{array}{c}\text { Action (giving } \\
\text { the 1st HOTS } \\
\text { based project, } \\
\text { presentation, } \\
\text { journal log) }\end{array}$ & $\begin{array}{c}\text { Observation } \\
\text { (observation } \\
\text { sheet, } \\
\text { questionnaire, } \\
\text { interview) }\end{array}$ & Reflection \\
\hline
\end{tabular}

\section{Cycle 2}

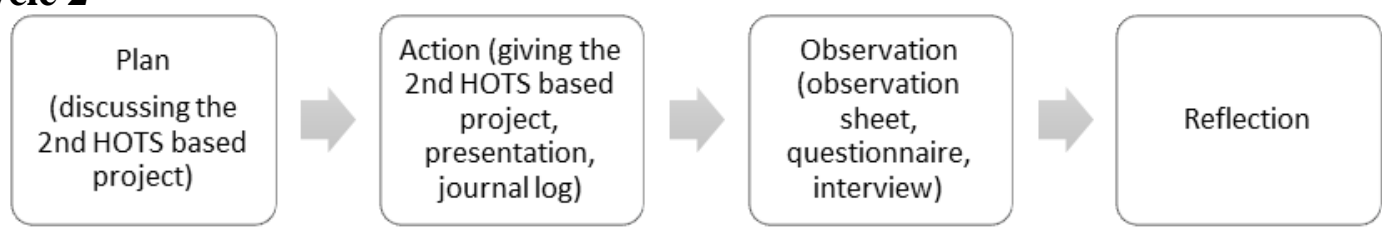

Fig. 2. Research Procedures

The analysis is done considering all instruments responses, reflecting the positive and negative responses on the HOTS based project to see the improvement of the English instruction. The qualitative data from the interview, journal log, and observation sheet were analyzed to confirm the general major students' experience, perception and thoughts about the given action (HOTS based project). Meanwhile, the quantitative data from the questionnaire were seen how the data numbers supported the qualitative data and from the test and presentation were seen how the achievement improved.

\section{Findings and discussion}

\subsection{Cycle 1}

\section{Identifying problem}

The problem was identified in Bahasa Inggris 1. The subject required the students to master grammar competence that most students were still unfamiliar because they were dominated by freshmen of grade 2018. Moreover, the grammar competence indicators stated in the curriculum were rather strict and difficult to be learnt using HOTS. When the lecturer asked the critical questions on particular grammar cases, the students still confused to answer. The students preferred to employ LOTS by memorizing the formula, understanding the examples, and applying the formula into the tasks. When the students were given homework to create a mind mapping on Conjunction, most of them copied and pasted the information into the mapping from the Internet without deeper analysis and evaluation.

The final mark in Bahasa Inggris 1 showed more evidence of the problems. The final average mark is 59.5 with the highest mark as 91 and the lowest mark as 22.9. It indicated that most students still needed to improve the English competence. The students with an A were 7 students, with a B were 17 students, with a $\mathrm{C}$ were 21 students, with a D were 21 students, and with an $\mathrm{E}$ were 4 students.

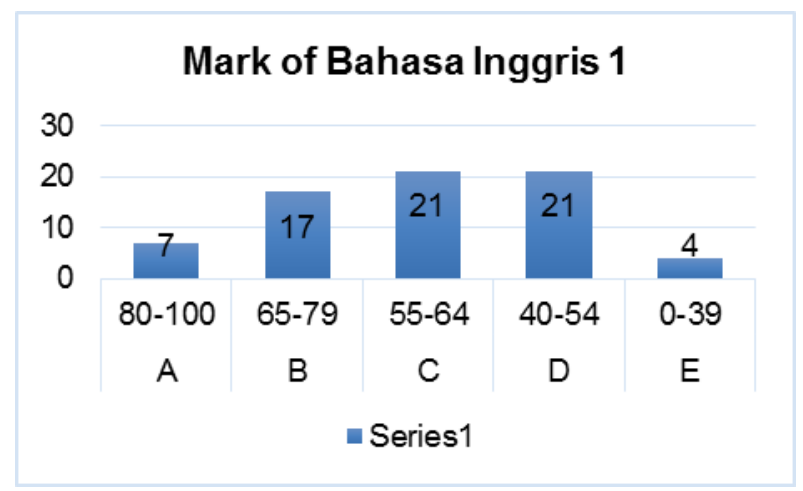

Fig. 3. Mark of Bahasa Inggris 1 
The data were supported by the first interview. It investigated the reasons of the low mark in Bahasa Inggris 1 and their learning strategies. The interview was conducted to the representative of students getting an $\mathrm{A}, \mathrm{a} \mathrm{B}, \mathrm{a}$, and a $\mathrm{D}$. The responses were summarized on Table 2 .

Table 2. Responses of the interview

\begin{tabular}{cl}
\hline No. & \multicolumn{1}{c}{ Responses } \\
\hline 1. & The English matters stated in the curriculum are grammar based that the students think they need to memorize a \\
2. lot of formula. & The students tend to use LOTS than HOTS. \\
3. The tests were mostly in the form of closed-ended questions. \\
4. The students used to think from formula to the examples.
\end{tabular}

The interview responses indicated two main problems. The first, the curriculum that composed learning objectives based on the grammar rules caused the students cannot use higher order thinking skills freely. The students preferred to find the formula, memorized the formula, and used the formula to answer the grammar questions. The second, the test in the final exam was composed using close-ended questions that the students did not have chance to answer in various ways. This also affected the less opportunity to use students' HOTS.

\section{Plan}

After the problem was identified, planning the first cycle was carried out. At the beginning, the lecturer discussed the plan on conducting an action research study for Bahasa Inggris 2 to the head of department and the result was he agreed and supported to do it. The lecturer proposed two cycles during the AR by selecting two course objectives. Under the head of department's suggestion, the selected course objectives were Tools and Aircraft construction. The reasons were both topics could be supported by the authentic materials available in the campus, both topics represented the demand of mechanical engineering with aerospace matters inside, and both topics were possible to be developed using HOTS based project. The consequence was that the order of the course objectives stated in the curriculum should be adapted. The order of the course consists of mathematics, energy and temperature, material technology, tool, pipe and pipeline, safety first, aircraft construction, basic flight instrument, flight line, aerodynamics, pre-flight, and future career. The changed was Tools and Aircraft construction were put orderly. HOTS based project was chosen because this technique can give positive impact in developing the students' critical thinking, communication, creativity, and collaboration which are very important the $21^{\text {st }}$ century education and it is possible to conduct. The campus has some workshop laboratories and a small hangar with three small airplanes that can be used for the students to finish the project.

\section{Action}

In this step, the first project based learning was given. Firstly, the students were arranged to work in groups of 4 or 5. Secondly, the students and the lecturer discussed the project on reporting mechanical engineering tools using PowerPoint. Each student should be responsible in describing 5 different tools, the functions, and how to operate them. Thirdly, they were assigned to go to places that they can find the tools such as mechanics, workshop laboratories, or hardware shops. They should take pictures holding each tool that the students know the authentic tools. Fourthly, in group, the students discussed the tools descriptions, functions, and how to operate them. The lecturer encouraged the students to find information from any reliable sources such as asking the mechanical engineering lecturers, workshops laboratories staff, and search in the Internet. The lecturer asked each group progress and gave feedback. Fifthly, the group created PowerPoint. In one PowerPoint slide, it should contain the picture of one student holding a tool, and some clues of the tools. The lecturer asked each group progress and gave feedback. Sixthly, the group presented the PowerPoint. After the presentation, the lecturer gave feedback.

To investigate the improvement of the first action, the condition before the action and after the action were compared. In this case, the mark of Bahasa Inggris 1 and the first presentation were compared. The project was marked based on the students' collaboration, creativity, critical thinking, and communication. The data were described on Figure 4 and Figure 5. 


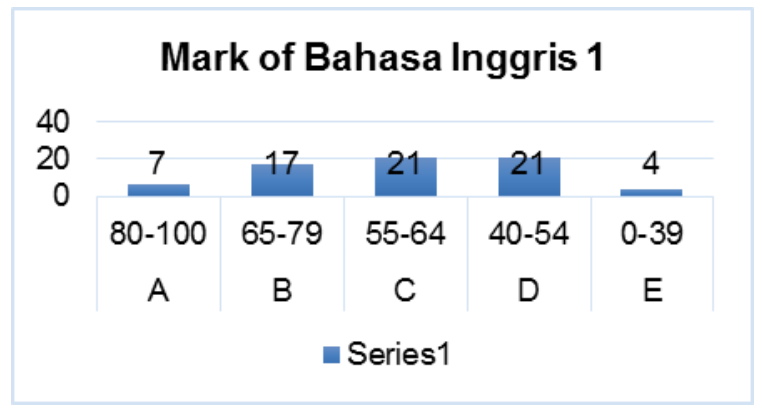

Fig. 4. Mark of Bahasa Inggris 1

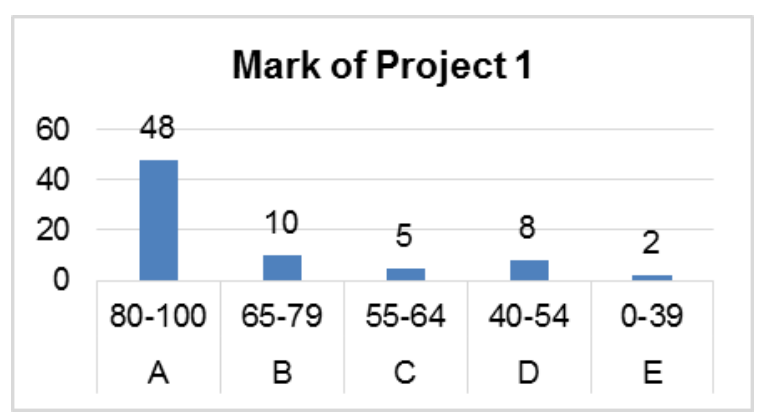

Fig. 5. Mark of Project 1

Both graph showed that there was an improvement in the students' achievement. In the Bahasa Inggris 1 , the mark was dominated by a $\mathrm{C}$ and $\mathrm{D}$ while in the Project 1 the mark was dominated by an A.

During the action, the students were equipped with journal logs to note their comments in completing Project 1 . The students were allowed to take the journal logs home to write the comments more freely and flexibly. The summarized responses were presented on Table 3 .

\section{Table 3.}

Journal Log of Project 1

\begin{tabular}{cl}
\hline No. & \multicolumn{1}{c}{ Responses } \\
\hline 1. & At the beginning, the students felt pessimistic to finish the project because this is the first time they had \\
this kind of project. \\
The students needed the examples of tools required in the project since the lecturer did not explain it \\
before. \\
The students later felt excited to have the project especially when they searched the tools in the \\
hardware shops then took pictures. \\
The students find some problems in determining clues written on the PowerPoint though finally they \\
enjoyed the process of creating PowerPoint and editing the pictures. \\
5. \\
The students felt nervous in presenting the PowerPoint. They felt unconfident in speaking. \\
At the last part, the students felt relieved completing Project 1.
\end{tabular}

The journal log indicated positive perception on the project based learning. The data showed pessimistic condition that changed into optimistic condition. The students were excited to complete the project and enjoyed the steps of completing Project 1, describing tools in mechanical engineering.

\section{Observation}

In the observation, the effects of project based learning were investigated by observing the students' behavior, distributing questionnaire, and conducting interview. The result of the observation is presented on Table 4. 
Table 4. Observation of Project 1

\begin{tabular}{cl}
\hline No. & \multicolumn{1}{c}{ Responses } \\
\hline 1. & The students were curious of the steps that they have to follow in Project 1. \\
2. & The students asked a lot of higher order thinking skills questions. \\
3. & The students worked collaboratively to collect the pictures from the authentic materials and find the \\
information in some sources. \\
4. The students found some problems and solve them critically by analyzing some data. \\
5. The students tried to develop the HOTS by analyzing the data, evaluating the data, and making the judgment of \\
6. tools presented in the PowerPoint.
\end{tabular}

The observation indicated that the students were fun with the project based learning. They showed the improvement in developing higher order thinking skills.

The observation was supported by the questionnaires of Project 1 that presented on Table 5.

Table 5.

Questionnaire of Project 1

\begin{tabular}{clccc}
\hline No. & \multicolumn{1}{c}{ Questions } & $\begin{array}{c}\text { Strongly } \\
\text { Agree }\end{array}$ & Agree & Disagree \\
\hline 1. & I could improve my communication skill & 31 & 30 & 1 \\
2. & I could improve my creativity & 33 & 29 & 1 \\
3. & I could improve my critical thinking & 34 & 29 & - \\
4. & I could be responsible in my cooperative learning & 27 & 32 & - \\
5. & I could work collaboratively with my group & 29 & 31 & - \\
6. & I was fun & 34 & 29 & - \\
\hline
\end{tabular}

The questionnaire supported the observation that demonstrated the positive responses on the project based learning. Two students said disagree that project based learning improved communication skill and creativity. Nevertheless, this is very small percentage that can be the suggestions for Project 2 in hope all students get the advantage of it. The following evidence were illustrated on Table 6 describing the second interview result on the students' perception after being given Project 1.

Table 6. Interview after Project 1

\begin{tabular}{cl}
\hline No. & \multicolumn{1}{c}{ Responses } \\
\hline 1. & The students felt satisfied of the achievement. \\
2. & The students felt excited that they could involve a lot of data to support their project. \\
3. The students felt happy they could study while hanging out since some of them visited hardware shops in a \\
mall. \\
4. The students felt motivated to use PowerPoint with only pictures and clues on the slide that they could \\
5. The students wanted to try other project works.
\end{tabular}

The students' perception from the interview supported the two previous data. They showed their hard working that resulted on the high mark. When they had problems, they use multi sources to finish the project. Moreover, the students could improve their communication in presenting the PowerPoint.

\section{Reflection}

The reflection was needed to find some suggestions for the following project. The overall processes of executing action research in Cycle 1 were recalled to formulate the reflection. The reflection is presented on Table 7 .

Table 7. Reflection of Project 1

\begin{tabular}{cl}
\hline No. & Reflection \\
\hline 1. & Motivation should be given that the students did not feel pessimistic anymore. \\
2. & The lecturer should give strategy in selecting word clues to be written on the PowerPoint. \\
3. & Some materials sources should be given before and during the project to support the project. \\
4. & Encouraging fast learners to help slow learners is important to succeed the project.
\end{tabular}


5. More challenging but attractive project could be given to enrich the HOTS development.

The reflection demonstrated that the lecturer should give clearer instruction, procedures, and material before giving the project. The lecturer should convince first that the students were ready and understood what to do in the whole project.

\subsection{Cycle 2}

\section{Plan}

The plan is done to prepare the second project based learning to improve the HOTS. The lecturer consulted the result of Project 1 to the head of mechanical engineering department. He suggested to give more students' opportunities that they can be independent learners with good HOTS. Project 2 was prepared to improve the students HOTS in identifying airplane components. They were assigned to report the name of the components, the position, the functions, and how to work.

\section{Action}

The action began with discussion between the lecturer and the students. They discussed 10 airplane components, the position, the function, and how they work from a book. The lecturer also gave the e-books of aviation dictionaries. Secondly, the students worked in group of 4 to 5 to discuss their plan in completing the project. Thirdly, the group reported the plan to the lecturer for asking feedback. Fourthly, the group went to hangar and airplane museum near the campus to find the pictures. The same as Project 1, one student was in charge in describing 5 components. Fifthly, the group discussed the pictures to the lecturer for feedback. Sixthly, the group discussed the components and found information from the dictionaries, books, aerospace lecturers, and Internet. Seventhly, PowerPoint was created containing pictures of airplane components and the clues for presentation. The lecturer gave feedback before the students presented the PowerPoint. The last, the group presented the project.

Compared to Project 1, this project was better. The mark increased as presented on Figure 6 and Figure 7.

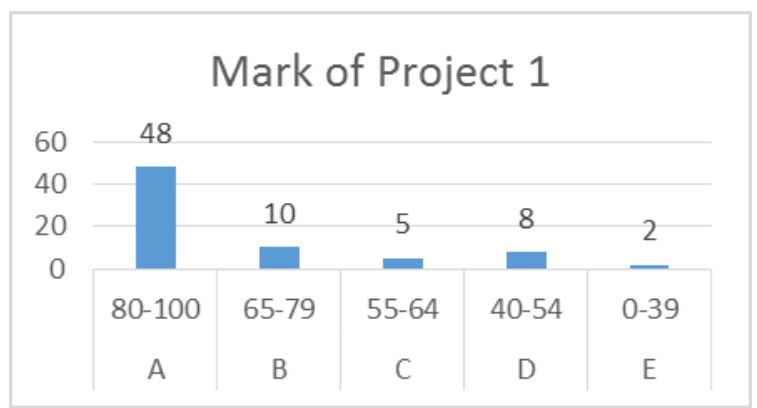

Fig. 6. Mark of Project 1

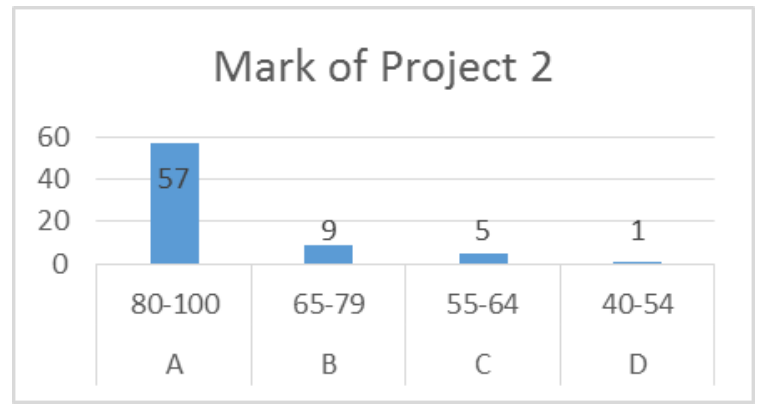

Fig. 7. Mark of Project 2

The graphs showed improvement on the students' project based learning. In Project 1, there were two students getting an E however in Project 2, there was no student getting an E. The A group 
increased from 48 to 57 students. During the action, the students were given the same instrument, journal $\log$ s to write their perception on the project. The result is presented on Table 8 .

Table 8. Journal Log of Project 2

\begin{tabular}{|c|c|}
\hline No. & Responses \\
\hline 1. & $\begin{array}{l}\text { The students were more confident to conduct the project though airplane component is a difficult material } \\
\text { in their study that they could not find before. }\end{array}$ \\
\hline 2. & The students could work in group better. Their collaboration increased in Project 2. \\
\hline 3. & The students could discuss more critically in sharing the airplane component project. \\
\hline 4. & The students could create better PowerPoint. \\
\hline 5. & The students were more confident in presenting PowerPoint and they spoke better. \\
\hline
\end{tabular}

The journal logs responses showed better performance and perception of the students on project based learning. They could use the skills in higher order thinking more in finishing Project 2. Even though airplane component is more challenging than tool, the students could finish it better.

\section{Observation}

The observation is conducted by writing the students' behavior during the project, distributing questionnaire, and interviewing. Table 9 showed the students' behavior during the project, Table 10 showed the questionnaire result, and Table 11 showed the interview responses.

Table 9.

Observation Finding of Project 2

\begin{tabular}{ll}
\hline No. & \multicolumn{1}{c}{ Responses } \\
\hline 1. & The students asked more critical questions about the airplane components. \\
2. & The students worked in group more collaboratively and critically. \\
3. & The students employed more Internet data (article, picture, and video) to analyze the airplane components. \\
4. & The students presented the PowerPoint more confidently. \\
\hline
\end{tabular}

Table 10. Questionnaire of Project 2

\begin{tabular}{clccc}
\hline No. & \multicolumn{1}{c}{ Questions } & $\begin{array}{c}\text { Strongly } \\
\text { Agree }\end{array}$ & Agree & Disagree \\
\hline 1. & I could improve my communication skill & 35 & 28 & - \\
2. & I could improve my creativity & 38 & 25 & - \\
3. & I could improve my critical thinking & 35 & 28 & - \\
4. & I could be responsible in my cooperative learning & 42 & 21 & - \\
5. & I could work collaboratively with my group & 45 & 18 & - \\
6. & I was fun & 40 & 23 & - \\
\hline
\end{tabular}

Table 11. Interview after Project 2

\begin{tabular}{ll}
\hline No. & \multicolumn{1}{c}{ Responses } \\
\hline 1. & The students understood better the steps in the project. \\
2. & The students were excited to observe the airplane components since the airplane body is very big and the \\
components are very complicated. \\
3. & The students could select the basic airplane components carefully to present. \\
4. & The students could employ their 4C skills better. \\
5. & The students could find the information more thoroughly in the Internet. \\
6. & The students presented the PowerPoint more confidently.
\end{tabular}

The three instruments were consulted. All of them showed the better improvement on the students' perception to the project based learning. Besides, the instruments also indicated the improvement on students' higher order thinking skills. Compared to the first cycle, the students applied more critical thinking before visiting the hangar and airplane museum to make sure that their plan complete orderly. In addition, they were more critical during creating the PowerPoint to convince that their works were correct. The more difficult materials on airplane components did constrain the students to develop their critical thinking. This condition precisely stimulated the students to be more critical. 


\section{Reflection}

The entire steps on the second cycle were recalled to present the feedback on reflection step. The data were summarized on Table 12.

Table 12. Reflection of Project 2

\begin{tabular}{|c|c|}
\hline No. & Reflection \\
\hline 1. & $\begin{array}{l}\text { It is important to give a project based learning in some various themes to develop the students' higher } \\
\text { order thinking skills. }\end{array}$ \\
\hline 2. & $\begin{array}{l}\text { It is important to discuss the plan before doing the project and make sure that the procedures and the } \\
\text { instruction are clear. }\end{array}$ \\
\hline 3. & $\begin{array}{l}\text { It is important to provide students with various material sources that the students can be more critical in } \\
\text { making judgment. }\end{array}$ \\
\hline 4. & $\begin{array}{l}\text { It is important to stimulate students to use the communication, creativity, collaboration, and critical } \\
\text { thinking to make the project. }\end{array}$ \\
\hline 5. & It is important to respond the students' questions critically that they can solve the problems. \\
\hline
\end{tabular}

It can be reflected that the students enjoyed the action and improved their higher order thinking skills. Some problems such as unclear instruction and students' confusion in selecting the materials sources would not appear on the following project anymore if the lecturer anticipate both problems before executing the project.

The analysis of the instruments were presented as follows.

\section{Interview}

The first interview was conducted to find the reasons why the students got low mark in Bahasa Inggris 1 subject. The result was the curriculum that focuses on the grammar based materials made the students difficult to develop higher order thinking skills (HOTS) and preferred to use low order thinking skills (LOTS). This condition motivated the lecturer to develop the students' HOTS using a technique, project based learning.

The second interview was conducted to observe the students perception after the first cycle. The result was the students improved their achievement. They were fun with the first project. They felt like hanging out in the hardware shops while doing an assignment. They also enjoyed searching information, editing the pictures and creating the PowerPoint for presentation. Furthermore, the wanted to have other projects.

The third interview was conducted after the second cycle. The result was the students were more confident in following the steps in the project. They employed more HOTS because the project was harder than the first project. The first project was about mechanical engineering tool while the second project was about airplane component. The students could find the tools in their daily life while the airplane components could not. This condition precisely motivated the students to ask more critical questions, selective in searching the data, and solved the problem collaboratively. In the presentation, they made more creative PowerPoint and improved their communication skills.

\section{Journal Log}

The journal logs were distributed to write the students perceptions during making the projects. The first journal indicated that the students were confused and not sure to complete the project because they have never got the typical project before. Nevertheless, they tried to search some information in some sources. After discussion the progress to the lecturer, the students had better feeling. The presentation ran well though their speaking needed to be improved. The second journal log was distributed during the second cycle. The journal showed that the students felt happy because the lecturer gave clearer instruction. They also showed the improvement on collaboration, critical thinking, creativity, and communication.

\section{Presentation}

The first presentation was conducted to evaluate the students' performance in describing mechanical engineering tools. Each student should present 5 tools in group of 4-5 so a group presented 20-25 tools. The result were compared to mark in Bahasa Inggris 1. The second 
presentation was used to evaluate the second project in describing airplane components. Similar to the first presentation, each student should present 5 components in group of 4-5 so a group presented 20-25 components. The table of mark were presented on Table 13.

Table 13. Comparison mark

\begin{tabular}{ccccc}
\hline Category & Range & Mark of Bahasa Inggris 1 & Project 1 & Project 2 \\
\hline A & $80-100$ & 7 & 48 & 59 \\
\hline B & $65-79$ & 17 & 10 & 9 \\
\hline C & $55-64$ & 21 & 5 & 5 \\
\hline D & $40-54$ & 21 & 8 & 1 \\
\hline E & $0-39$ & 4 & 2 & - \\
\hline
\end{tabular}

\section{Observation Sheet}

The observation was done by the lecturer during the completion of Project 1 and 2. It reported the students' behavior combined with the lecturer's perception of the project based learning to improve the higher order thinking skills. The first observation indicated that the students we curious of the project. This was something new for them. They started asking critical thinking questions about mechanical engineering tools. Though still need some assistance, they showed motivation in creating PowerPoint and preparing the presentation without reading the slides. Based on the second observation, the students enjoyed the project. They improved their collaboration in selecting the materials critically. They also showed better speaking in presentation.

\section{Questionnaire}

The first and second questionnaires were distributed to investigate the number of the students' perception. The data indicted positive perception on the project based learning to improve HOTS. Even though this is something new for them, most students agree even strongly agree that project based learning is able to improve the students' HOTS. 2 students in the first cycle said disagree that the project could improve their communication and creativity. However, in the second cycle, all students agree and strongly agree.

\section{Conclusion}

The research concluded that the projects based learning were able to improve the students' higher order thinking skills (HOTS). The students' responses also the students' performance indicated positive improvement on their HOTS. The projects allowed the students to work collaboratively in the authentic context, critically select the materials and ask questions, creatively create PowerPoint, and collaboratively present the PowerPoint. The three main skills in HOTS; transferring knowledge, critical thinking, and problem solving were shown in each project. The 4C skills; creativity, collaboration, critical thinking, and communication also supported the HOTS improvement.

For the following research, it is recommended to design more projects for other themes and involve more technologies. This project accommodated two among fourteen themes. It is expected that the following research can accommodate the other twelve themes. This research involved PowerPoint as the media for presentation. The next research is expected to involve other presentation media such as Canva, Padlet, or Moodle.

\section{References}

Andersen, A. S. \& Tinne, H. K. (2015). Theoretical Foundations of PPL at Roskilde University. In A. S., Andersen \& S. B., Heilesen (Eds), The Roskilde Model: Problem-Oriented Learning and Project Work (pp. 3-16). London, New York: Springer.

Ayoub, M. T. \& Jazib, S. K. (2017). ESP Needs Analysis of Undergraduate Engineering Students: A Case Study of Multan. Global Journal of Management and Social Sciences. Vol.3, No.1, Jan-March, 2017. Pg 103-119. 
Basturkmen, H. (2006). Ideas and options in English for specific purposes. New Jersey: Lawrence Erlbaum Associates.

Basturkmen, H. (2010). Developing Courses in English for Specific Purposes. New York: Palgrave Macmillan.

Bloch, J. (2013). The Handbook of English for Specific Purposes. In B. Paltridge, \& S. Starfield (Eds.),. Technology and ESP. West Sussex: Wiley-Blackwell, John Wiley \& Sons Ltd.

Brookhart, S. M. (2010). How to Assess Higher-Order Thinking Skills in Your Classroom. Virginia: ASCD.

Burns, A. (2010). Doing Action Research in English Language Teaching: A Guide For Practitioners. New York: Routledge.

Churches. A. (2008). Bloom's Digital Taxonomy. Retrieved May 23, 2019, from http://www.ccconline.org/wpcontent/uploads/2013/11/Churches_2008_DigitalBloomsTaxonomyGuide.pdf.

Dragoescu, A. \& Sandra, S. 2010. Quality Improvement of ESP in Mechanical Engineering. International Journal for Quality Research. Volume IV, No. 3, 2010.

Fajariyah, L. A. (2018). Proyek Infografis Berbasis Higher Order Thinking Skills (HOTS) dalam Pembelajaran Teks Report Di Kelas IX SMP N 5 Panggang Tahun Pelajaran 2017/2018. Retrieved from http://www.lailyenglish.com/2018/10/best-practice-hots-juara-i-fig-gk2018.html.

Henning, J. E., Stone, J. M., \& Kelly, J. L. (2009). Using Action Research to Improve Instruction: An Interactive Guide for Teachers. New York and London: Taylor \& Francis Routledge.

Heyworth, F. (2002). A Guide to Project Management. Graz: European Centre for Modern Languages.

Kaur, S. (2007). ESP course design: Matching learner needs to aims. English for Specific Purposes, $6(1)$.

Kemdikbud. (2017). Modul Penyusunan Soal Higher Order Thinking Skills (HOTS). Jakarta: Kemdikbud.

Krauss, J. \& Suzie, B. (2013). Thinking through Project-Based Learning: Guiding Deeper Inquiry. California: Sage.

Laur, D. (2013). Authentic Learning Experiences: A Real-World Approach to Project-Based Learning. New York: Routledge.

Ledward, B. C., \& Hirata, D. (2011). An overview of 21 st century skills. Summary of 21 st century skills for students and teachers. Honolulu: Kamehameha Schools-Research \& Evaluation.

Li, L. (2018). Integrating Technology in ESP: Pedagogical Principles and Practice. In R. MuñozLuna, \& L. Taillefer (Eds.),. Integrating Information and Communication Technologies in English for Specific Purposes (pp. 7-25). Switzerland: Springer.

McNiff, J., Lomax, P., \& Whitehead, J. (2002). You and Your Action Research Project. London and New York: Hyde Publications.

Nagappan, R. (2001). Language Teaching and The Enhancement of Higher-Order Thinking Skills. Language curriculum and instruction in multicultural societies. Anthology series 42. Singapore SEAMEO Regional Language Centre. 
Setiawan, A. \& Dwi A. L. B. (2018). Developing HOT Project-Based-Speaking Assessment to Stimulate the Students' Critical Thinking and Creativity. English Education Journal. Vol 3. (pp. 301-307).

Tan, J. C. L. \& Anne, C. (2016). Project-Based Learning for Academically-Able Students. Rotterdam: Sense Publishers.

Tomal, D. R. (2010). Action Research for Educators (Second Ed). New York: Rowman \& Littlefield Publishers. 